International Journal of Instruction e-ISSN: 1308-1470 • www.e-iji.net
October $2020 \bullet$ Vol.13, No.4

p-ISSN: 1694-609X

pp. 393-408

Received: 12/02/2019

Revision: 15/04/2020

Accepted: 05/05/2020

OnlineFirst:26/07/2020

\title{
EFL Students' Improvement through the Reflective YouTube Video Project
}

\section{Angela Bayu Pertama Sari}

M.Pd., Universitas Bina Sarana Informatika, Indonesia, angela.abp@bsi.ac.id

\section{Hanandyo Dardjito}

Ph.D., Universitas Sarjanawiyata Tamansiswa, Indonesia, dardjit@gmail.com

\section{Dinar Martia Azizah}

M.Pd., Universitas Sarjanawiyata Tamansiswa, Indonesia,dinar.azizah@ustjogja.ac.id

YouTube's contribution to EFL learning has made it an enticing learning media for students in this millennial era. YouTube created engaging atmosphere for learning English. Because of this, this study was carried out with two objectives in mind. The first objective was to reveal how factors in higher education affected the YouTube video project. The second objective was to provide evidence showing students' self-improvement in EFL learning via the YouTube video project. The data collected in this study was obtained from seventy-nine non-English speaking students in higher education. Data was collected via reflections written by the participating students. The content of these reflections was then synthesized and subsequently analysed. The analysis indicated that six factors influenced the reflection process of YouTube video project. These were as follows: behaviour, competencies, beliefs, environment, identity and mission. Additionally, the study indicated improvements in other areas such as the development of team work skills, ability to manage stress, technological ability and creativity. Especially in delivering information and enriching knowledge either the knowledge that was related to English learning or other types of knowledge in broader scope. Surprisingly, the study indicated that students' English language skills were not significantly increased compared to the result of the self-quality improvements.

Keywords: YouTube, video project, students' reflection, English learning, EFL

\section{INTRODUCTION}

Modern technology has developed significantly, and its impacts are inevitable on our lives. One of modern technology's positive impacts is in the improvement of education learning languages like English, has seen improvement due to the advance of technology (Dudeney \& Huckly, 2012). It is reported that a rapid advance of technology brings

Citation: Sari, A. B. P., Dardjito, H., \& Azizah, D. M. (2020). EFL Students' Improvement through the Reflective YouTube Video Project. International Journal of Instruction, 13(4), 393-408. https://doi.org/10.29333/iji.2020.13425a 
changes to teachers' and students'behaviour in foreign language learning (Danan, 2010). Traditional teaching and learning are textbook-based and teacher centered for language studies like English as a Foreign language (EFL). Contemporary learning and teaching in EFL have been transformed into a more engaging environment through the integration of abundant learning resources available on online platforms. Due to these learning improvements has become more creative, more time-efficient and costs have decreased because of ICT usage in EFL learning. This is consistent with Nikitina (2009) who proposes that an integration of technology and education has a significant role in creating teaching and learning experiences which are complete, memorable, engaging and fun for both the learners and their teachers.

The partnership of ICT in EFL learning is becoming more popular. The integration of YouTube in English learning is an example of this. Currently it is a platform which enables the users to share videos at no cost; furthermore, the users can earn money from the videos that they upload (Terantino, 2011). Additionally, Terantino (2011) adds that $73 \%$ of teenagers are categorized as YouTube active users. Moreover, the number of the YouTube users is increasing due to the nature of native digital users who heavily depend on technology and the internet. Due to its enormous potential, EFL learning takes advantage of using YouTube as a media for learning. Previous research showed that students in higher education voted YouTube as their favourite platform to learn English because it is attractive, useful, and strictly relevant to their life (Kelsen, 2009). Video projects build a learning experience that is more meaningful and engaging for students in the EFL learning (Marwan, 2015). The technique of video project assignments motivates students to get involved in the making of videos in addition to maintaining their engagement (Maria, 2017). Furthermore, the activity of making videos boosts students' technological ability and supports the peer learning process (Huang, 2015)

Previous research findings have revealed the value of the YouTube platform in its contribution to the EFL learning. Duffy (2008), For example, proposed the application of YouTube based projects for EFL learning. His method was to instruct students to create a video and upload it on YouTube, he then encouraged a discussion where in students provided and received peer-feedback related to their videos. Hafner and Miller (2011) reported that video projects gives learners a chance to create something meaningful related to their learning. Puspa (2016) suggests that the process of students making the video projects is effective in making a significant impact in the development of contemporary skills like knowledge creation, digital literacy and collaboration (Puspa, 2016). Additionally, YouTube based projects with discussion elements also enable learners to be motivated because they will receive feedback and comments from their peers which triggers them to reflect on their learning. The discussions on YouTube video projects help to establish students' critical awareness and encourage students to learn deeper as seen in the findings of Clifton and Maan (2011). Video project making also enhances students' skills in problem solving and group work in an exciting learning setting (Maldin \& Rezeki, 2017). Video projects have become a learning tool which is cognitively and emotionally challenging (Masats, et al., 2009). They do this by integrating the target language that is learned within the context of the lives of learners (Masats, et al., 2009). The video making process enables students to engage in peer- 
learning (Hafner \& Miller, 2011). These indicate that YouTube video projects bring positive impacts to education and learning in many disciplines (Franglinger \& Owens, 2009).

Orus C, et al (2016) stated that the learners' activities on generating video content on YouTube brings positive impact on the students' learning improvement and their learning satisfaction. Video projects are a potentially clever method for the teachers in conducting speaking activities. The application of learning activities video production as the teaching tools improve the students' speaking skills through their self-evaluation to their performances. Moreover, that activity makes the students more critical to their skills, especially speaking (Akdeniz, 2017).

Speaking is believed to be the most significant active skill for EFL learning (Widdowson, 1994). However, Khamkhien (2010) and Torky (2006) states that there are some speaking activity limitations such as the time-consuming learning activities and the unequal students' chances to speak. In order to cope with it, English teachers can use YouTube video project as an alternative way to provide an opportunity for the students to practice speaking. The goal is to pack the learning process to be more attractive and more contextual by containing real-world communication with some learning theory covered within it.

These previous research findings have vividly portrayed the significance of YouTube video project in EFL learning; however, they have not dug out the information in depth through the students' reflection. Those research findings tried to have a look from the students' point of view by using the students' reflection.

The importance of students' reflection in the learning process in the educational setting is well recognized. Dewey (1910) as cited in Marica (2015) claimed that the students do not learn from the learning process, they learn from the reflection instead. Through reflection, the students can capture their experience, digest it, and assess it. Thus, the reflection process leads to the discovery of new knowledge and even skills (Tan, 2002). Moreover, the sense of belonging to the lesson that the students' gain from the learning is relatively high since they have acquired the knowledge and skills by themselves through the reflective process. Rogers (2001) adds that in the process of reflection, a person must observe his or her both emotional and cognitive responses to the learning experience actively. It is done with the purpose to enhance his or her productivity and effectiveness to achieve better learning outcomes. Furthermore, Rogers (2001) also proposes four features in reflection: (1) the students should be actively engaged in the learning activity, (2) there should be a triggering situation or experience that is not common or surprising, (3) the students get a chance to discover their responses and thoughts to the activity that has been done, (4) the result proves the achievement of new understanding and knowledge to his or her experience.

To be more specific, this research tries to answer two research questions that were formulated as follows:

1. What are the factors that influence the reflection process of the EFL YouTube video project in higher education?

2. What are the students' self-improvements through the reflection process of the EFL YouTube video project in higher education? 
Furthermore, the objectives of this study aim at providing information on what factors that appear in the reflection process and to what extent YouTube video project contribute to the students' improvement

\section{METHOD}

This study employed a qualitative content analysis. The data collecting technique was done through direct observation in the classroom and collecting the students' written reflections. The researchers used observation checklist as a tool to record the students' attitude on the YouTube video project. The research participants were non-English students from Psychology study program in Sanata Dharma University, Indonesia. English is a compulsory course in all faculties. This study took Psychology major as the study subject since the English proficiency of Psychology students showed moderate and high proficiency of English. The students' proficiency was assessed by using diagnostic test in the beginning of the semester. The diagnostic test assessed their speaking skill. It was done through asking some questions and the students answered those questions directly one by one. Some language aspects were taken into consideration, such as the choice of vocabulary, the complexity of the utterances, fluency and pronunciation. Based on the diagnostic test, the result showed that the students were classified into the moderate learners (with the score 70-80) and proficient learners (with the score above 80 ). Thus, they had no language barrier in expressing their thoughts through the reflections.

The respondent in this study were 79 third-semester students who came from two different classes. They were around 19 years old consisting 25 male students and 54 female students. The researchers chose two classes to make the data diverse. Those students were chosen based on the purposive sampling as having moderate and high proficiency of English. They learned General English as the foreign language. The students were instructed to make a video project to practice their speaking skills. The lecturer gave the instruction to create a video that conveyed five points of information. There was no limitation in the topic and the duration was also not restricted. Then, the students were divided into groups that consisted of four to five people. The duration of the assignment was two weeks. The result of the video project was uploaded on to the YouTube platform. The lecturer also asked the students to promote the video so that the YouTube video content get some viewers, some likes and some comments from the YouTube viewers. The result of the uploaded videos was then played in the classroom. Finally, the students were asked to write a reflection related to the YouTube video project that had been accomplished. Those experiences were purposely done due to the nature of reflection for learning that required unusual or surprising experience so that the students were triggered to reflect on it (Rogers, 2001).

The data analysis in this study used content analysis. Downe-Wambolt (1992) emphasized that the goal of the content analysis is to create a relationship between the analytical result of the verbal, visual, written data to the context or to the background, which produced it. In details, Bengtsson (2016) formulated four stages in the content analysis process that is illustrated in Figure 1. 


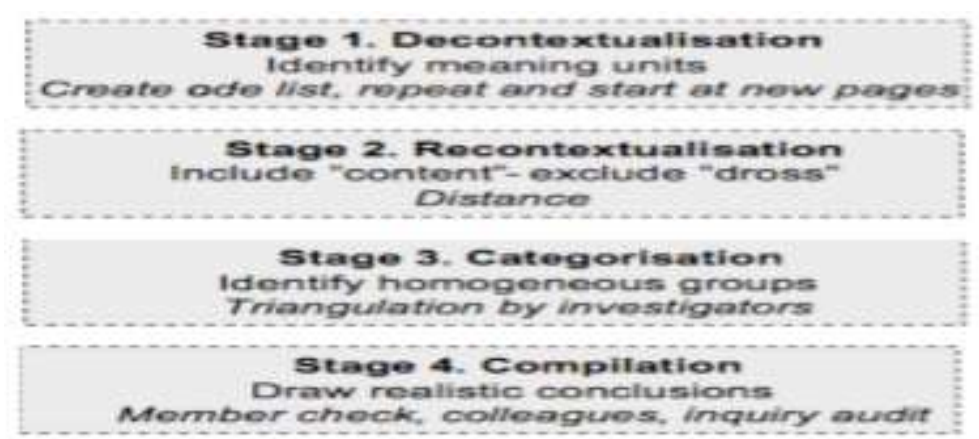

Figure 1

Content Analysis Stages (Bengtsson, 2016)

The content analysis requires existing theories or practices; the view and research results from some experts so that the researcher can construct the conclusion of each category (Krippendorff, 2004). Hence, the researcher inserted a theory dealing with the reflection content analysis to support the study. Korthagen and Vasalos (2005) proposed the onion model to dig out the factors influencing the reflective process result. It consisted of six levels affecting someone in functioning a specific role in life. It is described in Figure 2.

Korthagen and Vasalos (2005) elaborated the model as follows:

1. The environment is everything outside the person that he or she encountered.

2. Behaviour referred to an attitude that the person did that described how they behaved.

3. Competencies are related to any ability that a person can perform. It deals with the knowledge or skills that he or she mastered.

4. A belief is an assumption or conviction that was built by the person.

5. Identity deals with self-conceptualisation, how the person saw himself or herself.

6. A Mission is any calling, inspiration or hopes that play a role in a particular person's life.

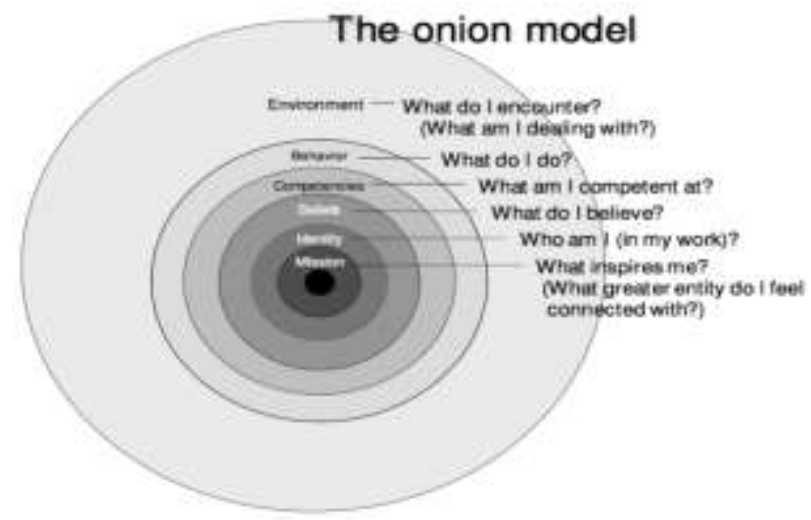

Figure 2

Six levels of reflection in the Onion Model (Korthagen \& Vasalos, 2005) 


\section{FINDINGS AND DISCUSSION}

\section{Students' Reflection Level Analysis}

Table 1

The Distribution of Students' Reflection Level

\begin{tabular}{ll}
\hline Level of Reflection & Frequency in the Students' Reflection \\
\hline Environment & 13 \\
Behaviour & 90 \\
Competencies & 58 \\
Beliefs & 27 \\
Identity & 9 \\
Mission & 9 \\
TOTAL & 206 \\
\hline
\end{tabular}

The data in the form of phrases were gained from the reflections of 79 students. The students were asked to write the reflection in papers. The length of the reflection was one paragraph that consisted of about five to ten sentences. In each student's reflection it yielded approximately 2 until 3 pieces of data in the form of phrases. Thus, the total items of data collected was 206.

The categorization was conducted with the core of the onion model (Korthagen \& Vasalos, 2005). The researchers classified the data based on the keywords that were written in the table in bold letters. For instance, the categorization of belief consisted of students' phrases that contained keywords "believe". For other categories, keywords become the key factor to determine in which category the data belong to.

The next discussion elaborated the details of each reflection's level, along with the impact on the students. Table 1 showed four factors with high frequency which impacted the YouTube Video project. These were behavior (90 responses), competencies (58 responses), beliefs (27 responses), and environment (13 responses). The low frequency factors were identity and mission ( 9 students each). The correct description of each category was elaborated in the following discussion.

\section{Environment}

Table 2

The Influence of the Environment on the Students' Reflection

\begin{tabular}{lll}
\hline $\begin{array}{l}\text { Reflections' } \\
\text { Level(category) }\end{array}$ & Reflection items & Frequency \\
\hline Environment & $\begin{array}{l}\text { We are aware of some obstacles in making the video } \\
\text { project such as the weather and other assignments with the } \\
\text { approaching deadline }\end{array}$ & \\
\hline
\end{tabular}

Several factors might influence a person in holding the role of their life; a professional setting in which they work. For instance, as EFL students, there were six levels of factors that may shape someone through their reflection (Korthagen \& Vasalos, 2005). The outermost level was the environment. According to the data of this research, it was illustrated that there was one item of reflection stated by 13 responses that they found some obstacles in making the YouTube video project. The two influences coming from the environment were the rain that caused the pending of the video shooting and the approaching deadline of other assignments that distracted the students' focus. However, 
the students became aware of those obstacles. The awareness was a good point that they could get from the reflection process; it allowed them to improve themselves in the future. This process of reflection created consciousness among the students about their actions and employed any possible trial and error to cope with the problem, in this case, the environment (Sööt \& Viskus, 2015).

\section{Behaviour}

The most prominent aspect of reflective learning that appeared in the research finding was behaviour aspect. It is the second biggest category that was reflected in 90 responses. It was illustrated in Table 2 that 28 responses revealed that YouTube video project enhanced the students' cooperation. It was consistent with Elgar (2002) who suggests that one of the advantages of the video project is supporting the dynamic of group cooperation. In the cooperation process, students got a chance to help each other with the same goal. YouTube video project also sharpened the students' tolerance towards their friends in the same group. This is also expressed by three students. Five students stated that they had been learning to respect and to dare themselves during expressing opinion practice. The students were braver to express their opinion for the sake of their group benefit and they also had more flexibility in accepting or refusing their friends' opinion. Students' motivation was also raised through this project. It was consistent with Dodson (2000) who states that EFL video project enhances English language learning along with the students' motivation.

Table 3

The Influence of Behavior on the Students' Reflection

\begin{tabular}{lll}
\hline Reflections' Level & Reflection items & Frequency \\
\hline & We practice group work and learn the dynamic of it. & 28 \\
\cline { 2 - 3 } & $\begin{array}{l}\text { We sharpen our patience, determination, motivation, and } \\
\text { spirit not to give up easily. }\end{array}$ & 4 \\
\cline { 2 - 3 } & $\begin{array}{l}\text { We developed our creativity in delivering information in an } \\
\text { attractive way. }\end{array}$ & 14 \\
\cline { 2 - 3 } Behavior & \begin{tabular}{l} 
It strengthens our relation among friends. \\
\cline { 2 - 2 }
\end{tabular} & 6 \\
\hline $\begin{array}{l}\text { We are aware of the obstacles that come from ourselves: too } \\
\text { much laughing \& being startled. }\end{array}$ & 6 \\
\hline We feel that this project become our media to have fun. & 24 \\
\cline { 2 - 3 } & We learn about tolerance. & 5 \\
\cline { 2 - 3 } & $\begin{array}{l}\text { We learn how to express our opinion and respect others' } \\
\text { opinion. }\end{array}$ & 5 \\
\hline
\end{tabular}

Currently, IT draws students' attention as a medium of learning language. Zakaria, Watson and Edwards (2010) stated that nowadays students incline to IT application in the language classroom. It is in line with the findings of this study which showed that the students had fun or excited in doing the YouTube video project. There were 24 responses in this study that showed the students' interest in the insertion of technology in the English language. They liked it because the learning process becomes more attractive and challenging than the traditional method.

The other result of this study revealed that there was an improvement in the students' creativity. The data from 14 responses yielded that YouTube video project or YouTube 
platform switched the way they delivered information from the conventional way to a more creative way. This result is in line with Chai and Tan (as cited in Jabar \& Ali, 2016) who pointed out that through YouTube video project, the students develop their higher order thinking skills that enabled them to produce ideas that manifested their creativity. The results of students' video project in this research are presented so creatively as seen in the observation of the classroom video screening.

The last finding showed that six responses showed the awareness of the obstacles of their non-verbal behavior such as too much laughing and being startled. Those two nonverbal behaviors hinder the process of video shooting; however, at the end of the video project they noticed their weaknesses so that in the future they might manage it better. It is consistent with Dickson (as cited in Carney \&Foss, 2008) who asserted that YouTube video project might give a positive impact on the improvement of student's non-verbal skill.

\section{Competencies}

The third level that gave impact to the students' reflection was competencies. It is the second biggest factor that influenced the students' reflection dealing with the YouTube video project. There were 58 responses who reflected the students' learning process related to competencies. Competencies dealt with every ability, skill and competence that the students did. Table 4 indicated the improvement of technological literacy was considered as the significant aspect since it was expressed by the biggest number of responses. Students' ability in editing the video ( 24 responses), shooting the video (7 responses), managing the video lighting (3 responses) and creating-uploading YouTube content (3 responses) was increased. Surprisingly, those technological masteries were improved within the EFL learning. Nejati (2010) and Lord (as cited in Jabar \& Ali, 2016) claimed that video project might prepare the students for their future computerbased communication; moreover, it shaped them to be autonomous learners. Thus, from the experience of making YouTube video project, the students got their autonomy in learning the technology by themselves. Furthermore, the activity of making video boosted students' technological ability and supported the peer learning (Huang, 2015)

Table 4

The Influence of Competencies on the Students' Reflection

\begin{tabular}{|c|c|c|}
\hline Reflections' Level & Reflection items & Frequency \\
\hline \multirow{8}{*}{ Competencies } & $\begin{array}{l}\text { We find it hard to speak up for the content video to be } \\
\text { uploaded in YouTube, and it is easier to speak up in the } \\
\text { classroom presentation rather than for video shooting. }\end{array}$ & 1 \\
\hline & $\begin{array}{l}\text { We enrich our knowledge from the informative content } \\
\text { video that we make. }\end{array}$ & 13 \\
\hline & We learn how to edit video. & 24 \\
\hline & We learn how to shot video. & 7 \\
\hline & We learn video lighting. & 3 \\
\hline & $\begin{array}{l}\text { We learn how to make improvisation when we practice } \\
\text { speaking. }\end{array}$ & 3 \\
\hline & It sharpens our translation skill. & 4 \\
\hline & $\begin{array}{l}\text { We enrich our knowledge about how to upload and create } \\
\text { online YouTube content. }\end{array}$ & 3 \\
\hline
\end{tabular}


The collaborative work occurred in the video project additionally gave them an opportunity for peer teaching either about mastering English language skills or technology literacy (Hafner \& Miller, 2011). Furthermore, the research results also portrayed the students' improvements in their English language skills. There were four students asserted that their translation skills and the skills in speaking dealing with spontaneous improvisation ( 3 responses) got better. It is in line with Warschauer and Grimes (2007) who believed that YouTube in its various forms had already increased students' oral, aural and writing ability.

The other finding showed students' improvement in their general knowledge and insight (13 responses). Vasudevan and Bateman (2010) accentuated a chance in choosing the topic by themselves that the students got due to the process of digital video making; consequently, in the process of video making, the students gained more meaningful knowledge. This insightful content achieved during the process was beneficial to broaden their view in life and their professional academic setting.

The next finding exposed that there was one student who found it hard to speak in English. She perceived that speaking in front of a camera was harder than speaking in front of her friends during a class presentation. This condition might happen due to the outcome of the speaking practice of video project that could be accessed publicly by anyone. It was explained by Hafner and Miller (2011) that the outcome of the video project is the publication of the video in the online platform through the internet which created broader access of future audiences, including their social network and audience worldwide. This condition then made that students felt so insecure in practicing English oral production; however, she kept trying despite her awareness of her limitation. The video screening observation in the classroom showed this student had already been able to conquer her limitation and performed well in the video. She then dominated the speaking portion in the video result. Thus, her awareness of the speaking limitation challenges herself to improve her speaking skill.

\section{Belief}

The next findings described the correlation of belief and the students' reflection. Based on the reflection, it was discovered that the students had a strong belief about the process of YouTube video project making. The results showed that nine responses revealed the students' feeling that the process of making a YouTube video project was not an easy thing to do. They were aware of the effort they needed to accomplish the project. The awareness was important for preparing them in the challenging real process. Moreover, the students also took the matter of preparation into account. Seven responses showed that the students realised about the importance of preparation; two responses said that mental preparation in overcoming the problematic situation in the group work was crucial. Those two responses showed that not all group work could run smoothly. Thus, they argued that preparing another plan was essential if the group work could not run well. Furthermore, the students had also been aware of a strategy to lessen down their burden in doing the video project. Jokes, humor and fun could make the process of video making to be more comfortable. It was due to the fresh and relaxed mind that created such a fun learning environment that it supported the video making process. The technique of video project assignment motivates the student to get involved in making 
the video and makes them entertained (Maria, 2017). This awareness to establish fun atmosphere was discovered by the students to be their learning strategy, which was useful to be implemented in the future situation.

Table 5

The Influence of Belief on the Students' Reflection

\begin{tabular}{lll}
\hline Reflections' Level & Reflection items & Frequency \\
\hline & $\begin{array}{l}\text { We believe that something fun can lighten up the video } \\
\text { making process. }\end{array}$ & 8 \\
\cline { 2 - 2 } & $\begin{array}{l}\text { We perceive that we must prepare ourselves and be willing } \\
\text { to sacrifice because not all friends can cooperate well in } \\
\text { making the video project. }\end{array}$ & 2 \\
\cline { 2 - 2 } Belief & $\begin{array}{l}\text { We believe that preparations create a better result. } \\
\begin{array}{l}\text { We believe that creating YouTube content is not an easy } \\
\text { thing. It needs a lot of processes. }\end{array}\end{array}$ & 9 \\
\hline $\begin{array}{l}\text { We feel that English is cool, especially when we can speak } \\
\text { fluently. }\end{array}$ & 1 \\
\hline $\begin{array}{l}\text { We believe that everything that we have can be shared to } \\
\text { others and will be meaningful for them. }\end{array}$ & 2 \\
\hline
\end{tabular}

The other finding showed that the students' belief established in this process was the awareness of sharing. In this context, the information shared was very important for the audiences. Even though the information was the simplest, the students perceived that it would be meaningful whenever it was shared with others. This awareness built a positive attitude concerning the students' willingness and active participation in sharing information with others, particularly the information that were delivered in the English language. This video project facilitated this awareness since broad audiences could access uploaded video through the internet platform worldwide (Hafner \& Miller, 2011).

The next belief is that students were proud of their ability to speak English fluently. Speaking English is getting more popular among youngsters nowadays. In Indonesia, the insertion of English terms in daily conversation will create such a cool image of someone. This belief carried a positive impact on the students so that they can be triggered to practice English.

The students' beliefs that were yielded from the YouTube video project may improve the students 'cultural awareness and belief (Gareis, 2000 as cited in Carney \& Foss, 2008). Moreover, the process of the video project making constructed the students' mind to discover their idea, insights and lesson learnt from the process; thus, the result the students' got is not a spoon-feeding knowledge that typically happened in the traditional classroom (Jabar \& Ali, 2016). The students progressed the way they believed in something through this process of learning.

\section{Identity}

The result in Table 6 indicated the acknowledgement of students' identity. There were seven responses showed that the students did not like the camera and acting. It was the reflection of their weaknesses dealing with oral performance in front of the camera. However, these students gave a solution to minimize their weaknesses by stating that 
they had to be more serious, brave and confident. Their outcome of creating a content could be viewed by the authentic broad audience motivating the students in conquering their anxiety in making the YouTube video project (Brook, 2011).

Table 6

The Influence of Identity on the Students' Reflection

\begin{tabular}{|c|c|c|}
\hline Reflections' Level & Reflection items & Frequency \\
\hline \multirow{4}{*}{ Identity } & I am aware that I am still struggling to speak English. & 1 \\
\hline & $\begin{array}{l}\text { I do not like camera, especially when the result is seen by } \\
\text { many people so that I have to be serious to satisfy the } \\
\text { cameraman. }\end{array}$ & 1 \\
\hline & $\begin{array}{l}\text { I do not like acting so I have to be braver and more } \\
\text { confident. }\end{array}$ & 6 \\
\hline & I feel so satisfied when the video is uploaded to YouTube. & 1 \\
\hline
\end{tabular}

The result of the students' identity showed that there was one response showed that the student was satisfied when her video had been uploaded on YouTube. It is in line with Hafner and Miller (2011) who stated that a video blog gave the student the opportunity to celebrate their achievement on the content of English videos that they uploaded. It was also a media to celebrate their effort and ideas that had been formulated in the video process that they struggle on, instead of spoon-feeding theory-based learning (Jabar \& Ali, 2016). The opportunity of celebration enhances the students' motivation in doing the video project the best that they could since they become more aware of the publication of their video project result.

The acknowledgement of the students' identity dealing with the inability of speaking English well was illustrated in Table 6. A student who previously found talking in English was challenging considered the challenge was not a dead end. It is due to the nature of YouTube video project that served as an alternative media of expression for the weaker learner in English language learning (Bull \& Kajder, 2004 as cited in Jabar $\&$ Ali, 2016). Thus, the identity of the student who felt poor in speaking skills can be accommodated through the process of YouTube video project.

\section{Mission}

The last analytical category was a mission. The mission became the innermost level of the students' reflection. The mission encouraged the students to set a plan for their future. The data in Table 7 revealed that eight responses reflected the students' awareness of their plan in the future after they have accomplished the YouTube video projects. It is in accordance with Procee (2006) who claimed the process of reflection triggered the students to be more aware of their self-knowledge and steered their selfdevelopment. It was indicated that their plans were all positive towards the English learning and the development of IT skill. There was one response that showed the student's plan to take an English course next semester to improve her English skills. Also, seven students set a plan to create other YouTube videos. They believed that creative contents that were posted on YouTube might inspire people who watch it. This belief is consistent with Vasudevan and Bateman (2010) who pointed out that digital videos posted in YouTube gave the creator an opportunity to deliver content that was meaningful for life. 
Table 7

The Influence of Mission on the Students' Reflection

\begin{tabular}{lll}
\hline Reflections' Level & Reflection items & Frequency \\
\hline \multirow{3}{*}{ Mission } & I'm planning to take an English course next semester. & 1 \\
\cline { 2 - 3 } & I'm planning to create other videos to inspire people. & 7 \\
\cline { 2 - 3 } & I have to be able to work in any condition in the future. & 1 \\
\hline
\end{tabular}

The result from table 7 showed that there was one response that revealed the student's plan to improve his professional abilities to adapt to the demand of his job. Those three types of students' mission proved that YouTube video project could encourage the students to set further innovative plans for the benefits of themselves and their circumstances.

According to the result and discussion above, the researchers pointed out that the two formulated questions in the study had been answered. The first answer to the first study question dealt with the factors that gave impact to the reflection process. There were 6 factors, namely: environment, behavior, competencies, belief, identity and mission. The first factor is environment, it created consciousness among the students about their actions and employed any possible trial and error to cope with the problem, in this case, the environment (Sööt \& Viskus, 2015). The second factor was behavior. The study conducted by Chang (2019) showed that the students' reflection about the online learning indicated positive result. The students felt that the learning encouraged them to establish social interaction with their peers. The third factor was competencies. The study that was carried out by Hussein (2018) revealed that the students' reflection towards the learning could enhance the students' understanding about the English concept and build new knowledge. The fourth factor was belief. The study result was supported by Ruchajat (2018) who illustrated that the students felt that the video making process was beneficial and meaningful for them to increase the speaking skill. The fifth factor was identity. It was in line with the study conducted by Kizilcik and Daloglu (2018) which portrayed that the students' reflection on their learning performance might help them to acknowledge their strengths and weaknesses. The sixth factor was mission. The study that was conducted by Cavilla (2017) showed similar findings that was through the learning reflection, the students were encouraged to think and solve the assignment. Furthermore, most of the students were more motivated to improve their performances in the learning process.

The second study question was about to what extent reflection process of the EFL YouTube video project gave impact to the students' improvement. The finding showed that there was some improvement in the students' skill such as skills to use the technology and stress management. However, the English skill surprisingly did not really improve. The result was on the contrary with Oranpattanachai (2018) study that showed the improvement of English skills through the video project making. The success of the study conducted by Oranpattanachai (2018) was due to the specific instruction that required the students to use phrases or expressions that were written in the textbook. This difference made was the main distinction that made the result of those two studies different. 


\section{CONCLUSION}

YouTube has increasingly become popular in EFL learning. The video project provided EFL learners' the opportunity to improve themselves innovatively. This research derived evidence from the individual reflections of participating students related to the impact of the YouTube video project for EFL learning. The reflection was conducted through paper-based system. The findings revealed that factors which impacted the students' reflective process were: behaviour, competencies, beliefs, individual mission for future action, individual awareness of self-identity and the influence of their surrounding environment. Additional findings revealed significant improvements in other areas such as: the ability to navigate group work, creativity in delivering information, mental management skills - in relation to task enjoyment, technology literacy and their general knowledge. Since the students had various interests in the topics for their video projects, it contributed to their classmates' knowledge. For example, they have information on the college students' life, tips for travelling, and tips for make-up. The unexpected finding was that English skill/proficiency was not the major students' improvement.

The instructional objectives in this research were to develop the students' Englishspeaking skill and to motivate the students to be engaged in classroom activities. However, the students paid more attention to technical issues such as the YouTube platform, shooting, lighting, and editing the video. The students paid less attention to the improvement of their speaking skills. The instructions for making the video did not emphasize speaking skills, so the students were un aware that the main teaching objective was developing their speaking skills. It was suggested that teachers inform the students of the assessment rubric for the project in advance so that they would have additional guidance for the learning criteria of the project.

The study yielded some implications (1) that the selection of the video project topic which was based on the characteristics of the students who were so close with the technology had a positive impact which increased enthusiasm regarding the problem solving process; (2) that the information which was needed by students during the process of the video project was not merely the detailed instructions but also the learning goals and a rubric for the assessment criteria so that they could self-assess whether they meet the expected standards or not; (3) that it was essential for the lecturers to assess and monitor the process of the video making project periodically so that any problems could be solved immediately; (4) that because the video making project was done in a groups, it established lifelong skills of group communication and team-building which are essential in the working environment; (5) that the students' reflection was an essential medium for the lecturers to measure how effective their teaching methods were.

This study showed that students' reflections are a valuable tool for lecturers as they provide feedback for both the information which is being retained by students who are learning and the attitude in which they proceed with a project. Thus, this type of activity is expected to be conducted more often. Moreover, this study showed it is crucial to encourage lecturers to provide more solutions to the problems of learning in a modern context. This study also lead to the conclusion that reflection activities should be 
undertaken by not only students but also lecturers in the form of teaching reflections. This conclusion lead to the assertion that the information would be more useful when a juxtaposition of both students' and lecturers' views was utilized to form better structures to maximize the learning process. If further study was to be conducted, it is suggested that an investigation of the role of the English project as a tool to build meaningful learning experiences for students should be considered.

\section{REFERENCES}

Akdeniz, N. Ö. (2017). Use of student-produced videos to develop oral skills in EFL classrooms. In. Journal on Language, Literature and Culture in Education, 4(1), 43-53.

Bengtsson, M. (2016). How to plan and perform a qualitative study using content analysis. NursingPlus Open, 2, 8-14.

Brook, J. (2011). The affordances of YouTube for language learning and teaching. Hawaii Pacific University TESOL Working Paper Series, 9(1), 2.

Carney, N., \& Foss, P. (2008). Student-produced video: Two approaches. English Teaching Forum, 46(2), 14-19.

Cavilla, D. (2017). The Effects of Student reflection on academic performance and motivation. Sage Open, 7(3), 1-13.

Chang, B. (2019). Reflection in learning. Online Learning, 23(1), 95-110.

Clifton, A., \& Mann, C. (2011). Can YouTube enhance student nurse learning? Nurse Education Today, 31(4), 311-313

Danan, M. (2010). Dubbing projects for the language learner: A framework for integrating audiovisual translation into task-based instruction. Computer Assisted Language Learning, 23(5), 441-456.

Dodson, S. L. 2000. FAQs: Learning languages through drama. Texas Papers in Foreign Language Education, 5(1), 129-41.

Downe-Wamboldt, B. (1992). Content analysis: method, applications, and issues. Health Care for Women International, 13(3), 313-321.

Dudeney, G., \& Hockly, N. (2012). ICT in ELT: How did we get here and where are we going? ELT Journal, 66, 533-542.

Duffy, P. (2008). Engaging the YouTube google-eyed generation: Strategies for using Web 2.0 in teaching and learning. The Electronic Journal of e-Learning, 6(2), 119-130.

Elgar, A. G. (2002). Student playwriting for language development. ELT Journal, 56(1), $22-28$

Fralinger, B., \& Owens, R. (2009). YouTube as a learning tool. Journal of College Teaching \& Learning, 6(8), 15-28.

Hafiz Zakaria, M., Watson, J., \& Edwards, S. L. (2010). Investigating the use of Web 2.0 technology by Malaysian students. Multicultural Edu. \& Technology J., 4(1), 17-29. 
Hafner, C. A., \& Miller, L. (2011). Fostering learner autonomy in English for science: A collaborative digital video project in a technological learning environment. Language Learning \& Technology, 15(3), 68-86.

Huang, H. C. (2015). The effects of video projects on EFL learners' language learning and motivation: An evaluative study. International Journal of Computer-Assisted Language Learning and Teaching (IJCALLT), 5(1), 53-70.

Hussein, H. (2018). Examining the effects of reflective journals on students' growth mindset: a case study of tertiary level EFL students in the United Arab Emirates. IAFOR Journal of Education, 6(2). 33-50.

Jabar, N., \& Ali, A. M. (2016). Cultural video project assignment (VPA) through the eyes of young ESL learners: A multi-modal vocabulary learning approach. Indonesian Journal of EFL and Linguistics, 1(2), 2016.

Kelsen, B. (2009). Teaching EFL to the iGeneration: A survey of using YouTube as supplementary material with college EFL students in Taiwan. Call-EJ On., 10(2), 1-18.

Khamkhien, A. (2010). Teaching English speaking and English speaking tests in the Thai context: A reflection from Thai perspective. Eng. Lang. Teaching, 3(1), 184-190.

Kizilcik, H., \& Daloglu, A. (2018). Implementing an interactive reflection model in EAP: optimizing student and teacher learning through action research. Australian Journal of Teacher Education, 43(9), 1-27.

Korthagen, F., \& Vasalos, A. (2005). Levels in reflection: Core reflection as a means to enhance professional development. Teachers and Teach: Theo. and Prac., 11(1), 47-71.

Krippendorff, K. (2004). Content analysis: An introduction to its methodology. Thousand Oaks, CA: Sage.

Maldin, S. A., \& Rezeki, S. R. I. (2017, October). Stepping up the English speaking proficiency of hospitality students through video blogs (Vlogs). In Sixth International Conference on Languages and Arts (ICLA 2017). Atlantis Press.

Maria, A. D. (2017). Creating video and speaking achievement in EFL classroom. ELTE Journal (English Language Teaching and Education), 5(1), 76-86.

Marica, A. (2015). Becoming a reflective educational professional: an interpretative phenomenological analysis of students' experiences (Unpublished master thesis). University of Twente.

Marwan, A. (2015). Empowering English through project-based learning with ICT. Turkish Online Journal of Educational Technology-TOJET, 14(4), 28-37.

Masats, D., Dooly, M., \& Costa, X. (2009, July). Exploring the potential of language learning through video making. In Proceedings of the EDULEARN09 Conference. 6th8th July. 
Nikitina, L. (2009). Student video project as a means to practice constructivist pedagogy in the foreign language classroom. Journal of Educators \& Education/Jurnal Pendidik dan Pendidikan, 24.

Oranpattanachai, P. (2018). thai engineering students' perceptions of video project assignments. LEARN Journal: Language Education and Acquisition Research Network Journal, 11(1), 170-182.

Orús, C., Barlés, M. J., Belanche, D., Casaló, L., Fraj, E., \& Gurrea, R. (2016). The effects of learner-generated videos for YouTube on learning outcomes and satisfaction. Computers \& Education, 95, 254-269.

Procee, H. (2006). Reflection in education: A Kantian epistemology. Educational Theory, 56(3), 237-253.

Puspa, A. (2016). Student-made video project to enhance students' learning experience. Proceedings of ISELT FBS Universitas Negeri Padang, 4(1), 69-79.

Rogers, R. (2001). Reflection in higher education: A concept analysis. Innovative Higher Education, 26(1), 37-57.

Ruchajat, L. (2018). Making a video as an alternative task to improve the students' motivation to practice speaking English: the case at grade VII B of SMP N 1 Ungaran. English Education Journal, 8(3), 395 - 402

Sööt, A., \& Viskus, E. (2015). Reflection on teaching: A way to learn from practice. Procedia-Social and Behavioral Sciences, 191, 1941-1946.

Tan, K. S. (2002). Reflective learning in the classroom. REACT, 2, 101-109.

Terantino, J. M. (2011). Emerging technologies YouTube for foreign languages: You have to see this video. Language Learning and Technology, 15(1), 10-16.

Torky, S. A. E. (2006). The effectiveness of a task-based instruction program in developing the English language speaking skills of secondary stage students (Unpublished doctoral dissertation). Ain Shams University.

Vasudevan, L., Schultz, K., \& Bateman, J. (2010). Rethinking composing in a digital age: Authoring literate identities through multimodal storytelling. Written Communication, 27(4), 442-468.

Warschauer, M., Shetzer, H., \& Meloni, C. F. (2000). Internet for English teaching. Alexandria: Tesol.

Widdowson, H.G. (1994). Teaching Language as Communication. Oxford: Oxford U. 